\title{
Agora Paleobotanica
}

\section{Zhangwuia: an enigmatic organ with a bennettitalean appearance and enclosed ovules}

\author{
Zhong-Jian Liu ${ }^{1}$, Ye-Mao $\mathrm{Hou}^{2}$ and Xin Wang ${ }^{3 *}$
}

${ }^{1}$ Key Laboratory of National Forestry and Grassland Administration for Orchid Conservation and Utilization at
College of Landscape Architecture, Fujian Agriculture and Forestry University, Fuzhou 350002, China.
${ }^{2}$ Key Laboratory of Vertebrate Evolution and Human Origin of Chinese Academy of Sciences, Institute of
Vertebrate Paleontology and Paleoanthropology, Beijing 100044, China.
${ }^{3}$ CAS Key Laboratory of Economic Stratigraphy and Palaeogeography, Nanjing Institute of Geology and
Palaeontology and Center for Excellence in Life and Paleoenvironment, Nanjing 210008, China.
Email: xinwang@nigpas.ac.cn
* Corresponding author

ABSTRACT: The feature distinguishing typical angiosperms from gymnosperms is that their ovules are enclosed before pollination. Bennettitales were formerly related to angiosperms because of the flower-like organisation of the former's reproductive organs. There is little information on how the naked ovules of Bennettitales became enclosed in angiosperms because fossil evidence for such a transition, if it exists, has not been described. Here, we report a reproductive organ, Zhangwuia gen. nov., from the Middle Jurassic of Inner Mongolia, China. Like many Bennettitales, the arrangement of the foliar parts around the female part in Zhangwuia demonstrates a resemblance to typical angiosperm flowers. It is noteworthy that the ovule is secluded from the exterior space in Zhangwuia, therefore implying the existence of angio-ovuly. Although Bennettitales have been related to angiosperms for more than a hundred years, their way of ovule-enclosing was not previously revealed. The discovery of Zhangwuia prompts a rethinking of the relationship between Bennettitales and angiosperms, as well as of the origin of angiosperms.



KEY WORDS: angiosperms, Bennettitales, China, Inner Mongolia, Middle Jurassic.

Angiosperms are unequivocally the most important plant group for human beings and current ecosystems. They are commonly characterised by their unique reproductive organs; i.e., flowers. In spite of all the effort invested in flowers, where they came from has long been a puzzle for botanists. Arber and Parkin related the female part of Bennettitales with the gynoecium of Magnolia and declared the latter as the most primitive angiosperm (Arber \& Parkin 1907). Almost all plant systematicists have been heavily influenced by this hypothesis. The morphology and anatomy of the female parts of Bennettitales, in which the ovules, with exserted micropylar tubes, are surrounded by interseminal scales, were welldocumented in the last century (Wieland 1906; Seward 1919; Rothwell \& Stockey 2002, 2010; Stockey \& Rothwell 2003; Crane \& Herendeen 2009). Ironically, the more that is learned of Bennettitales, the greater the gap between Bennettitales and angiosperms appears to be. A magnoliaceous carpel was thought to be derived from a foliar part bearing ovules along its margins (Eames 1961; Cronquist 1988; Dilcher 2010). However, relating the female part of Bennettitales to conduplicate magnoliaceous carpels is now problematic because evidence favouring this hypothesis has been lacking. Conversely, evidence negating this hypothesis is continuously emerging (Liu et al. 2014; Miao et al. 2017; Zhang et al. 2017).

Numerous plants and insects have been found in the Daohugou region (Zheng et al. 2003; Ji et al. 2004; Huang et al. 2006; Zhou et al. 2007; Ren et al. 2009, 2010; Wang et al. 2010b; Zheng \& Wang 2010; Wang \& Zhang 2011; Peng et al. 2012), and there is general consensus on the Middle Jurassic age of the Jiulongshan Formation (formerly Daohugou Formation) (Ren et al. 2002; Zhang 2002, 2006; Shen et al. 2003; Li et al. 2004; Liu et al. 2004; Ji et al. 2005; Huang et al. 2006, 2008a, b, 2009; Huang \& Nel 2007, 2008; Petrulevicius et al. 2007; Sha 2007; Zhou et al. 2007; Lin et al. 2008; Liu \& Ren 2008; Selden et al. 2008; Zhang et al. 2008, 2009, 2011; Chang et al. 2009, 2014; Liang et al. 2009; Shih et al. 2009; Wang et al. 2009a, b, c, 2010a; Wang \& Ren 2009; Wang \& Zhang 2009a, b). $\mathrm{Ar}^{40} / \mathrm{Ar}^{39}$ and SHRIMP U/Pb datings have been performed on the volcanic rocks in the overlying Tiaojishan Formation (Chen et al. 2004; Ji et al. 2004), suggesting an age of at least $164 \mathrm{Ma}$ for the fossiliferous Jiulongshan Formation. In addition to various animal fossils (especially insects), abundant fossil plants have been reported from this region. According to current literature, the Daohugou flora includes algae of one species (within the Chlorophyceae), four genera and six species of bryophytes (Daohugouthallus, Metzgerites, Muscites, Ningchengia), two genera and two species of Lycopodaceae (Lycopodites, Selaginellites), two genera and two species of sphenophytes (Annularia, Equisetites), four genera and six species of Filicales (Coniopteris, Osmunda, Eboracia, Sphenopteris), seven genera and 12 species of cycads (Pterophyllum, Anomozamites, Nissoniopteris, Williamsonia, Weltrichia, Cycadolepis, Tyrmia), four genera and four species of Czekanowskiales (Czekanowskia, Solenites, Leptostrobus, Ixostrobus), 


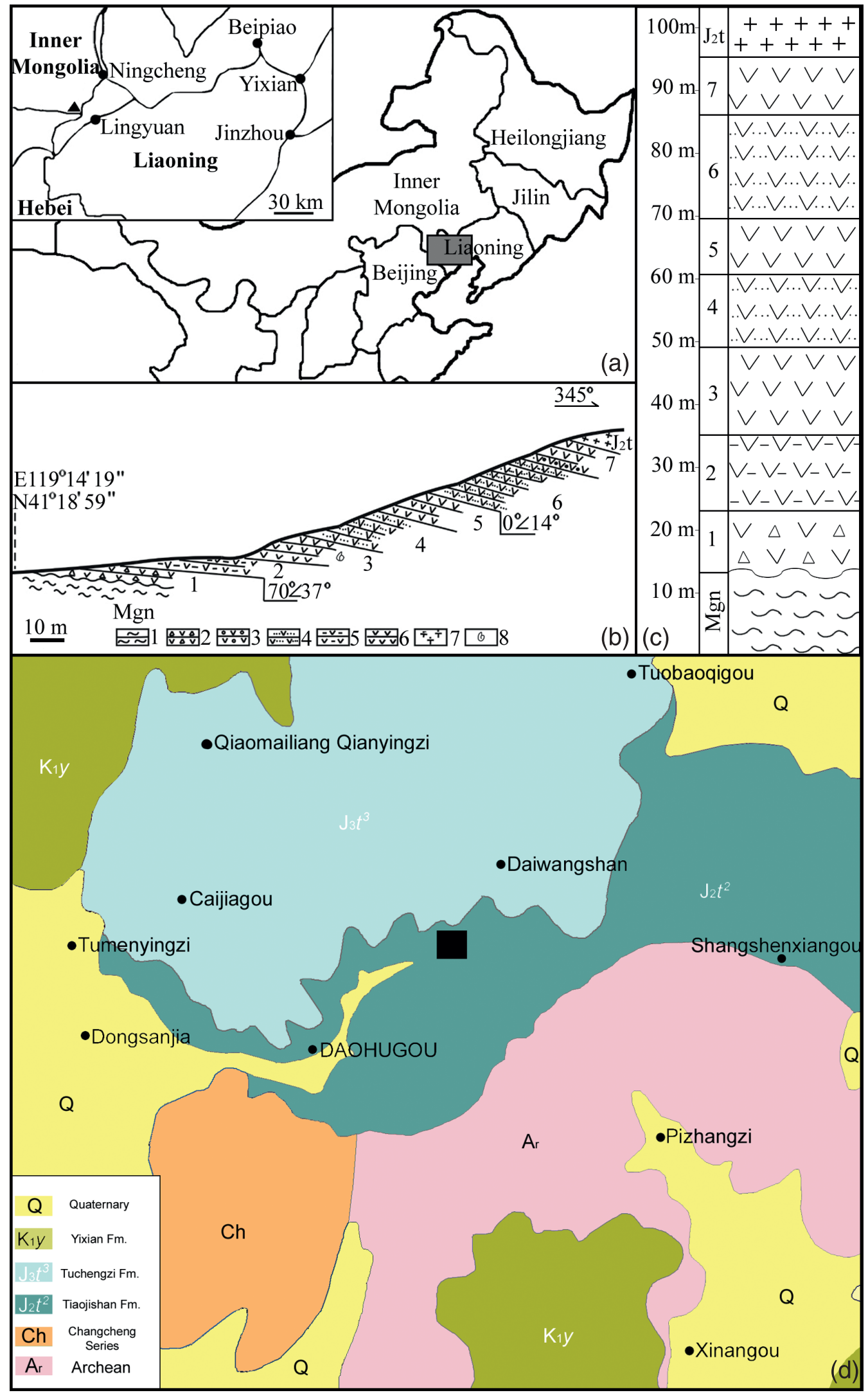

Figure 1 Geological information for the Jiulongshan Formation at Daohugou Village. Modified from Tan \& Ren (2009): (a) geographical position of the fossil locality, Daohugou Village, Ningcheng, Inner Mongolia, China. The rectangular region is shown in detail in the inset, in which the black triangle represents Daohugou Village and the black dots represent cities in the region. (b) Geological section of the Jiulongshan Formation near Daohugou Village. Layer 3 is the major fossil-yielding layer: $1=$ gneiss; $2=$ tuffaceous grand conglomerate; $3=$ tuffaceous conglomerate; $4=$ tuffaceous siltstone; $5=$ tuffaceous mudstone; $6=$ tuffaceous shale; $7=$ volcanic breccia; 8 = fossil locality. (c) Stratigraphic column of the Jiulongshan Formation near Daohugou Village. Layer 3 is the major fossil-yielding layer. (d) Geological map of Daohugou Village and adjacent region. Rectangle represents the fossil locality. 

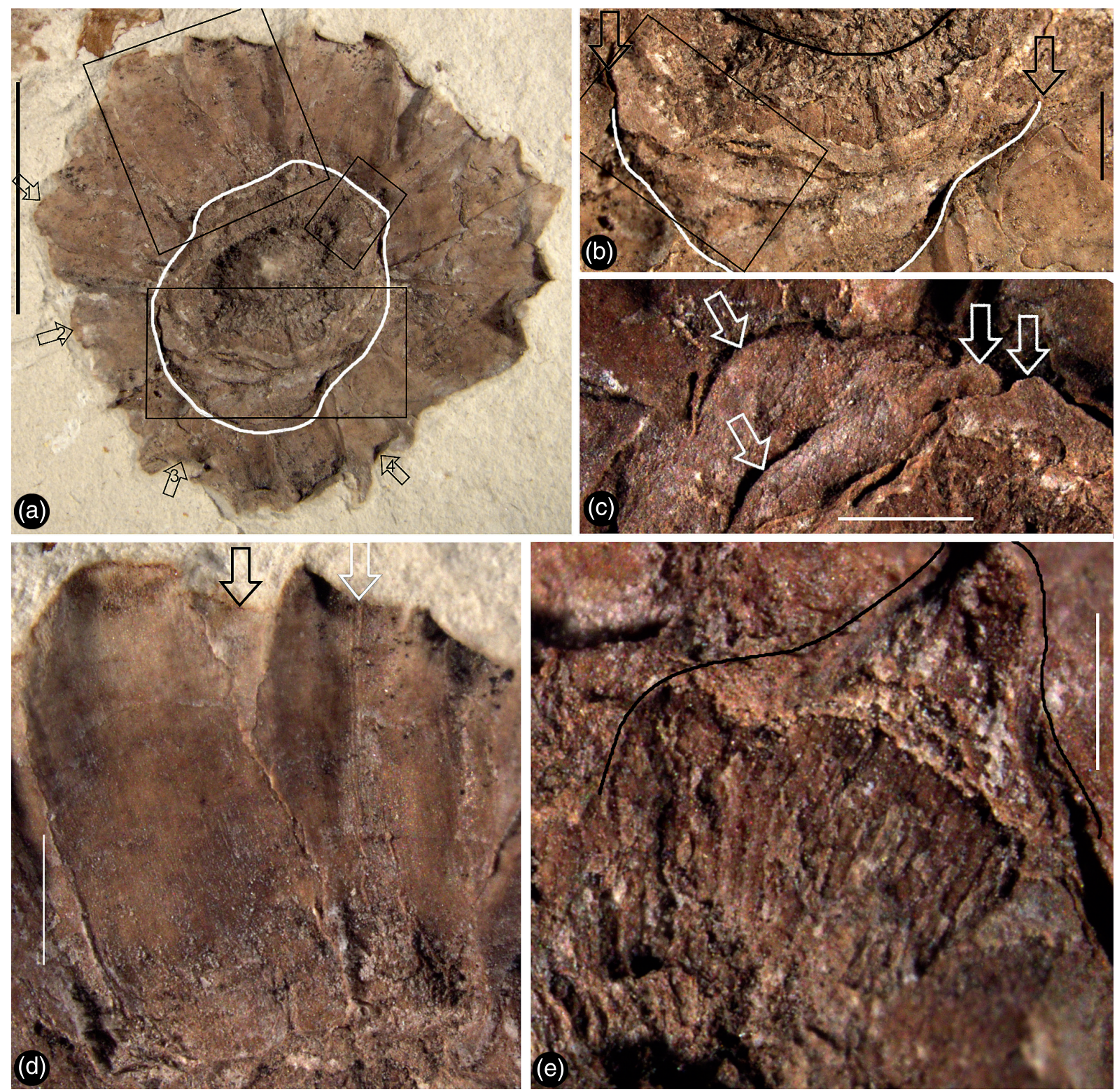

Figure 2 Zhangwuia mira gen. et sp. nov. and its details. Stereomicroscopy. Holotype, PB21675: (a) the organ with radially arranged inner foliar parts surrounding the central female part (white outline). Rectangles show position of enlargements (b-e); (b) partial view of the organ, enlarged from the lower rectangle in (a), showing the border (white line and arrows) between the inner foliar parts and female part, as well as the border (black line) between receptacle and the female units; (c) detailed view of the female part, enlarged from the rectangle in (b), showing several tips (arrows) of spirally arranged female units; (d) three partially overlapping inner foliar parts, enlarged from the upper rectangle in (a) - the left one has an obtuse tip and no midrib, while the right one has a bent tip and a midrib (white arrow), and note a third inner foliar part (black arrow) in the background; (e) a broken female unit (outline) exposing its internal details, enlarged from the small rectangle (a) (see Fig. 5 b, c). Scale bars $=5 \mathrm{~mm}(\mathrm{a}) ; 1 \mathrm{~mm}(\mathrm{~b}-\mathrm{c}) ; 0.5 \mathrm{~mm}(\mathrm{e})$.

four genera and six species of Ginkgoales (Yimaia, Ginkgoites, Baiera, Sphenobaiera), 13 genera and 20 species of Coniferales (Pityocladus, Pityospermum, Schizolepis, Austrohamia (Yanliaoa), Brachyphyllum, Elatocladus, Amentotaxus, Taxus, Nageiopsis, Podocarpites, Cephalotaxopsis, ?Pseudofrenelopsis, Podozamites), two genera and two species of Caytoniales (Caytonia, Sagenopteris), three genera and three species of seeds/fruits with unknown affinities (Conites, Problematospermum, Carpolithus), and three genera and three species of angiosperms (Solaranthus, Juraherba, Yuhania) (Zheng et al. 2003; Li et al. 2004; Zhou et al. 2007; Wang et al. 2010a, b; Zheng and Wang 2010; Pott et al. 2012; Heinrichs et al. 2014; Dong et al. 2016; Han et al. 2016; Liu \& Wang 2016b). As reported here, these works converge on a Middle Jurassic age for Zhangwuia.
Recently, a bennettitalean plant, Foxeoidea, was reported with its ovules surrounded by interseminal scales, although its ovules were not fully enclosed as they are in angiosperms (Rothwell \& Stockey 2010). To help bridge this gap between Foxeoidea and typical angiosperms, we here report a fossil reproductive organ, Zhangwuia gen. nov., from the Jiulongshan Formation of the Middle Jurassic ( $>164 \mathrm{Ma}$ ) of Daohugou Village, Inner Mongolia, China $\left[119^{\circ} 15^{\prime} \mathrm{E}, 41^{\circ} 19^{\prime} \mathrm{N}\right]$. Zhangwuia demonstrates a great resemblance to angiosperm flowers, including its flower-like organisation, surrounding foliar parts, and, most importantly, angio-ovuly in the female part. Interestingly, the general morphology of Zhangwuia demonstrates a resemblance to Bennettitales. Such a mosaic combination of characters implies that at least some Bennettitales have 

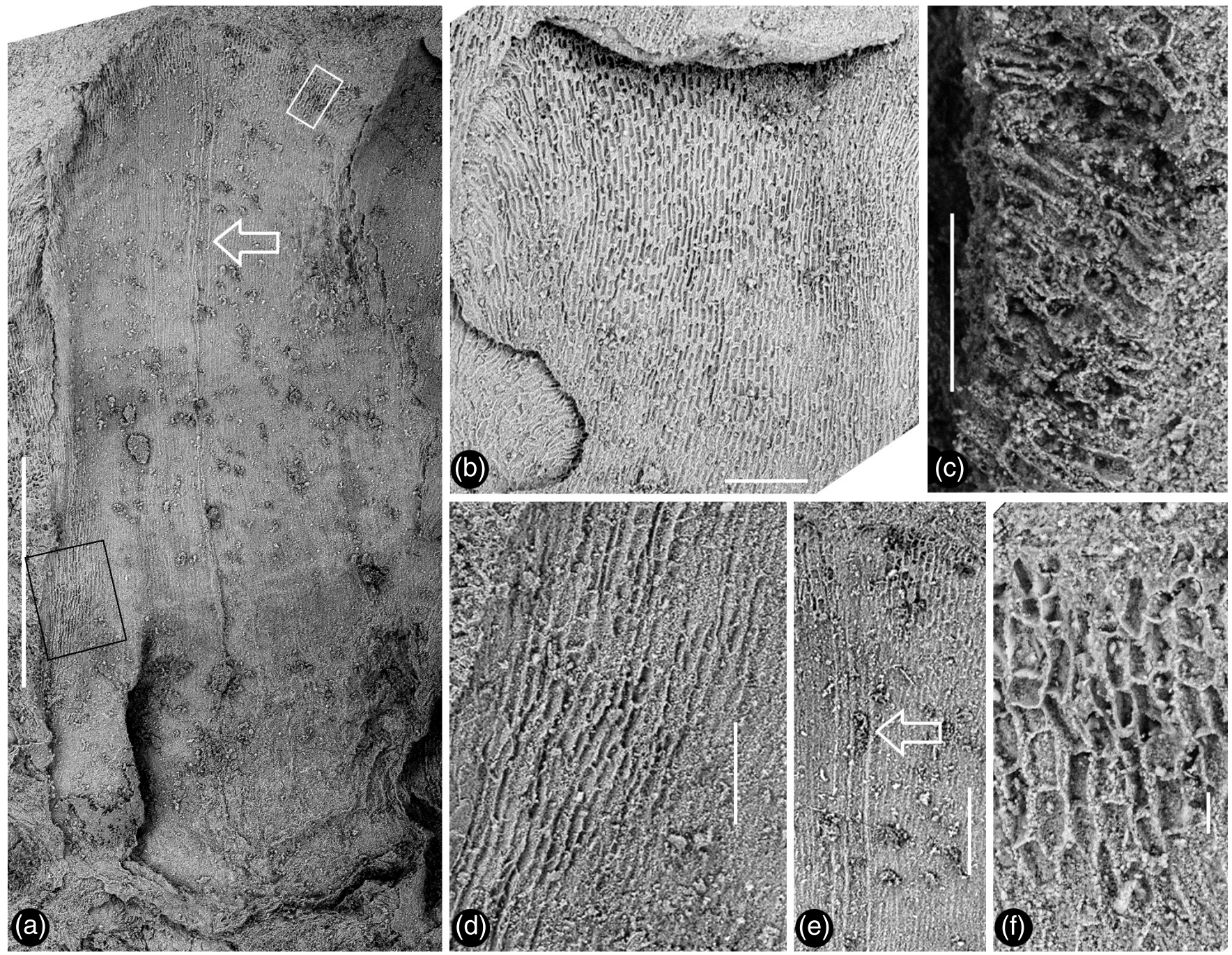

Figure 3 Detailed views of the inner foliar parts of Zhangwuia mira gen. et sp. nov. SEM: (a) an inner foliar part with a midrib (arrow) and an obtuse tip, the no. 1 arrowed part in Fig. 2a; (b) an inner foliar part with a bent tip (top) and no midrib, the no. 4 arrowed part in Fig. 2a; (c) detailed view of a bent tip of an inner foliar part, showing cellular details, from the no. 3 arrowed part in Fig. 2a; (d) cellular details on the margin of an inner foliar part, enlarged from the black rectangle in Fig. 3a; (e) detailed view of the middle portion of the inner foliar part (arrow in Fig. 3a), showing the midrib (arrow); (f) cellular details of the distal portion of the inner foliar part, enlarged from the white rectangle in Fig. 3a. Scale bars $=1 \mathrm{~mm}(\mathrm{a}) ; 0.2 \mathrm{~mm}(\mathrm{~b}, \mathrm{e}) ; 0.1 \mathrm{~mm}(\mathrm{c}, \mathrm{d})$; $20 \mu \mathrm{m}(\mathrm{f})$.

the potential to reach angio-ovuly. In this way, Zhangwuia could narrow the evolutionary gap between angiosperms and gymnosperms.

\section{Material and methods}

The fossil material was collected by a local fossil collector, Mr Hongtao Cai, from the outcrop of the Jiulongshan Formation near Daohugou Village, Ningcheng, Liaoning, China $\left(119.236727^{\circ} \mathrm{E}, 41.315756^{\circ} \mathrm{N}\right.$; Fig. 1$)$, and it was donated to the Nanjing Institute of Geology and Paleontology, Chinese Academy of Sciences (CAS).

The general morphology and details of Zhangwuia were observed and photographed using a Nikon SMZ1500 stereomicroscope with a digital camera. More details were further observed and recorded using a Leo 1530 VP scanning electron microscope (SEM) at the Nanjing Institute of Geology and Palaeontology (NIGPAS), Nanjing, China. Micro-computed tomography (CT) observation was performed using $225 \mathrm{kv}$ micro-CT (developed by the Institute of High Energy Physics, CAS) at the Key Laboratory of Vertebrate Evolution and Human Origin of CAS in the Institute of Vertebrate Palaeon- tology and Palaeoanthropology, scanning under a cone-beam energy of $130 \mathrm{kV}$ and a flux of $100 \mu \mathrm{A}$ with an $8.8 \mu \mathrm{m}$ slice distance. The transmission images of 1536 slices were reconstructed with a $2048 \times 2048$ matrix and $8.8 \mu \mathrm{m}$ pixel size through a $3 \mathrm{D}$ image processing software developed by the Institute of High Energy Physics, CAS. The images were processed using VGStudio Max2.2. The final results were saved as images or videos. All photographs were organised together for publication using Photoshop 7.0.

To make our description more neutral, we use the terms 'female part' and 'female unit', instead of 'gynoecium' and 'carpel' (which are restricted to angiosperms) to describe the morphology of Zhangwuia.

\section{Results}

Order Incertae sedis

Family Incertae sedis Genus Zhangwuia gen. nov.

Generic diagnosis. Reproductive organ of radial symmetry. Outer foliar parts inflated, more or less rounded, probably 


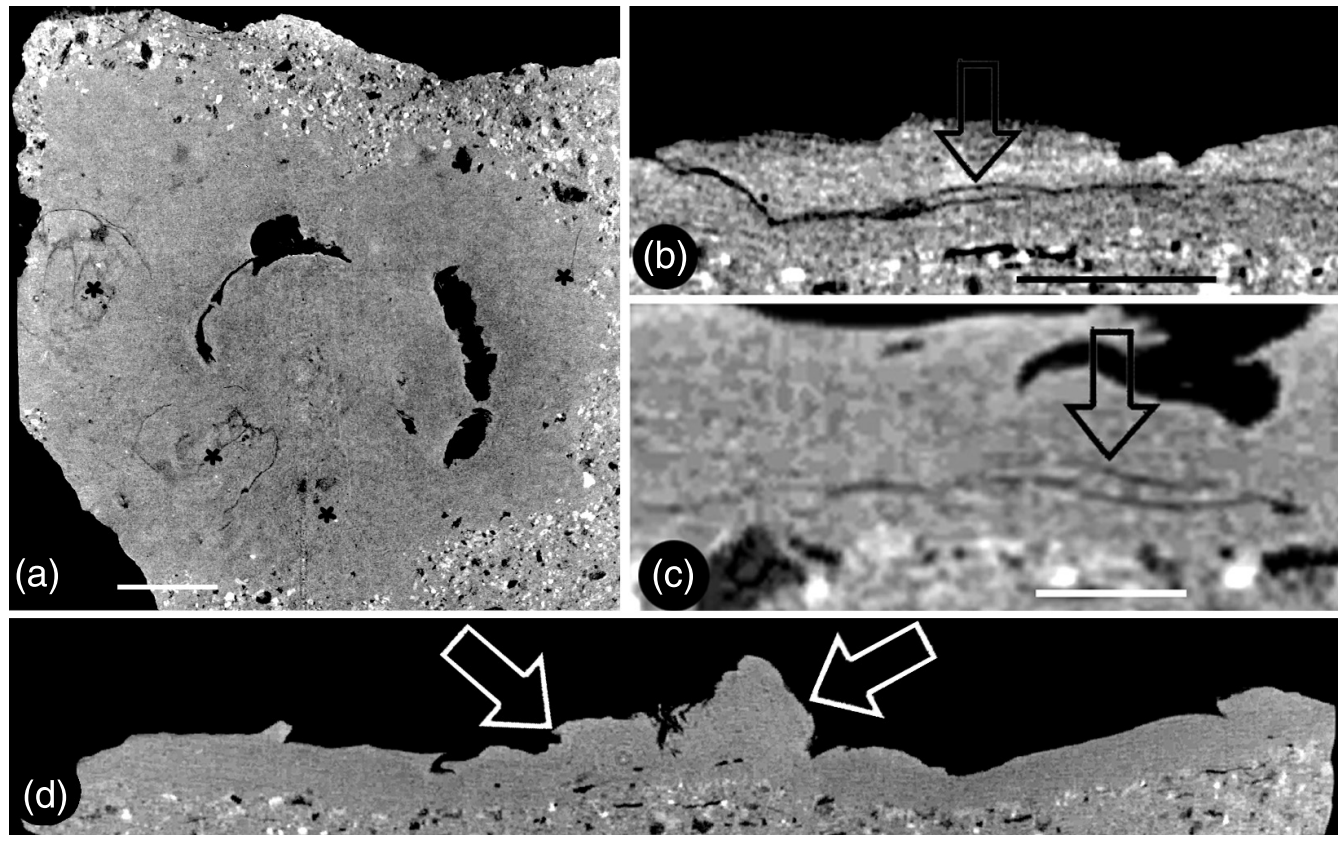

Figure 4 Micro CT virtual sections of Zhangwuia mira gen. et sp. nov.: (a) snapshot of the video showing the organ in cross section. Two of the outer foliar parts are visible in this view. The positions of the outer foliar parts are marked with asterisks. For more information, see supplementary materials, available at https://doi.org/ 10.1017/S1755691018000257. (b) Tangential section of the organ showing the cross view of an outer foliar part with an inflated portion (arrow) in the middle bottom. (c) Radial section of the organ showing a longitudinal view of the outer foliar part shown in Fig. 4b, with an inflated portion (arrow) near its base. The organ centre is to the right. (d) Longitudinal central section of the organ showing the female unit (left arrow) and the central protruding receptacle (right arrow). Scale bars $=2 \mathrm{~mm}(\mathrm{a}) ; 1 \mathrm{~mm}(\mathrm{~b}, \mathrm{c})$.

seven in number, radially arranged. Inner foliar parts above the outer foliar parts, radially arranged, in three cycles, approximately seven per cycle, alternate, tongue-shaped, obtusetipped, some with a weak midrib. Female part includes numerous spirally arranged female units. Female unit with secluded space, a blunt tip, and an ovule/seed inside.

Type species. Zhangwuia mira gen. et sp. nov.

Etymology. Zhangwu - for the senior Chinese palaeobotanist, Professor Wu Zhang (8 August 1937-27 June 2016).

Horizon. The Jiulongshan Formation, Middle Jurassic.

Age. The Callovian, Middle Jurassic (>164 Ma).

Locality. Daohugou Village, Ningcheng, Inner Mongolia, China $\left[119^{\circ} 15^{\prime} \mathrm{E}, 41^{\circ} 19^{\prime} \mathrm{N}\right]$.

\section{Zhangwuia mira gen. et sp. nov.}

(Figs 2-5)

Specific diagnosis. (In addition to that of the genus) Organ at least $12 \mathrm{~mm}$ in diameter. Outer foliar parts $4.3 \mathrm{~mm}$ long and $3.4 \mathrm{~mm}$ wide. Inner foliar parts approximately $4 \mathrm{~mm}$ long and $1.8 \mathrm{~mm}$ wide. Female part approximately $6 \mathrm{~mm}$ in diameter at the base. Female unit approximately $1.2 \mathrm{~mm}$ long, fused basally with adjacent units.

Description. The fossil is brown in colour, embedded in yellowish tuff, preserved in three dimensions, and the exposed part is approximately $12 \mathrm{~mm}$ in diameter (Figs 2a, 4a, d; supplementary video V1). The organ includes outer and inner foliar parts and female part (Fig. 2a, b). The outer foliar parts are not visible to the naked eye but can be visualised through the application of micro-CT (Fig. 4a; supplementary video V1). The positions of the individual outer foliar parts imply that there may be seven outer foliar parts (Fig. 4a; supplementary video V1). Each outer foliar part is approximately $4.3 \mathrm{~mm}$ long and $3.4 \mathrm{~mm}$ wide, more or less rounded, with an inflated portion in the middle base (Figs $4 \mathrm{a}-\mathrm{c}$; supplementary videos V1-V3). The inner foliar parts include approxi- mately 23 members preserved alternately in three cycles (Fig. $2 \mathrm{a}, \mathrm{d})$. Each inner foliar part is approximately $4 \mathrm{~mm}$ long and $1.8 \mathrm{~mm}$ wide, with straight parallel entire margins and an obtuse tip, attached to the receptacle with its whole base, with a longitudinally oriented epidermal texture (Figs 2a, d, $3 a, b, d-f)$. Some of the inner foliar parts may have weak midribs (Figs 2d, 3a, e) or tips bent adaxially (Figs 2a, d, 3b, c). The cells are approximately $45-50 \mu \mathrm{m}$ long and $7-13 \mu \mathrm{m}$ wide in the lateral regions of the inner foliar parts, and approximately $30-80 \mu \mathrm{m}$ long and $19-24 \mu \mathrm{m}$ wide in the midrib region of the inner foliar parts (Fig. 3d-f). The female part is approximately $6 \mathrm{~mm}$ in diameter, conically formed, tapering distally, and bearing spirally arranged female units (Figs 2a-c, 4d, 5e; supplementary videos $\mathrm{V} 1-\mathrm{V} 2$ ). The centre of the female part was replaced with sediment during the fossilisation (Fig. 2a, b). The peripheral tissue of the female part is broken, exposing the details of the female units (Figs 2e, 5a-c). The female unit is up to $1.9 \mathrm{~mm}$ long and $1.7 \mathrm{~mm}$ wide, and fused with neighbouring units basally (Figs 2c, e, 5e). The surface of the female units is integral, with epidermal cells $50-80 \times 20-50 \mu \mathrm{m}$ (Figs 2c, 5d, e). There is a secluded locule, separated from the exterior space by a $0.2-\mathrm{mm}$-thick wall, inside each female unit (Fig. 5a, d). An ovule isolated from the locule wall is seen inside the female unit (Fig. 5d)

Specimen number. PB21675.

Etymology. mira for mirus, meaning 'wonderful' in Latin.

Depository. The Nanjing Institute of Geology and Palaeontology, Nanjing, China.

\section{Discussion}

'Carpel' is a frequently used term in angiosperm morphology. There are at least two usages of this term. First, carpel sensu lato designates any structure that encloses the ovules; namely, the basic unit of angiosperm gynoecium. Second, a carpel sensu stricto designates a foliar part enclosing ovules/seeds. 



Figure 5 Details of female part of Zhangwuia mira gen. et sp. nov. SEM. (a) Tip (top arrow) of female unit and the margin (lower arrows) of its locule. Inset shows the outline of the locule wall. (b) Details of the female unit shown in Fig. 2e. Note the outline of the female unit (black line) and margin (white line) of the locule. (c) Surface (white line) of the female unit and margin (arrows) of the locule, enlarged from Fig. 5b. (d) An ovule (o) partially covered by other tissue, and a locule wall (between two upper arrows). Note the gap between the ovule and locule wall (between two lower arrows). Refer to the inset. (e) Tips (arrows) of two spirally arranged female units with integral surface. Refer to Fig. 2c. (f) Epidermal cellular details on the tip of a female unit. Scale bars $=0.2 \mathrm{~mm}(\mathrm{a}, \mathrm{d}) ; 0.1 \mathrm{~mm}(\mathrm{~b}, \mathrm{c}, \mathrm{f}) ; 0.5 \mathrm{~mm}(\mathrm{e})$.

The carpel sensu stricto is hinged with the assumption that a carpel is derived from a megasporophyll, bearing ovules along its margins (Arber \& Parkin 1907). This assumption has constituted the foundation for angiosperm systematics for more than a hundred years. However, a 'sporophyll' is purely an imaginary part that has never been seen in any fossil or extant plant (Wilson 1937; Melville 1963; Miao et al. 2017) because all ovules are borne on branches rather than on leaves (Herr 1995) and the only leaf-like 'megasporophyll' seen in Cycas is a result of mechanical pressure from the adjacent ovulates parts during the development (Wang \& Luo 2013). Deciphering how the angiospermous carpel can be derived from the bennettitalean female part has been difficult for botanists. Until this question is answered satisfactorily, it is impossible to securely establish any of the hypotheses concerning the relationship between angiosperms and Bennettitales, as well as the systematics of angiosperm. Therefore, bridging the gap between angiosperms and Bennettitales using fossil evidence is of crucial importance for plant systematics.

The resemblance between Zhangwuia and Bennettitales is conspicuous. Bennettitales are a fossil group that have been well-documented by various authors in the past century
(Wieland 1906; Seward 1919; Rothwell \& Stockey 2002; Stockey \& Rothwell 2003; Crane \& Herendeen 2009; Rothwell \& Stockey 2010). The inner foliar parts surrounding the female part in Zhangwuia are comparable to the foliar parts surrounding the female part in Bennettitales (Watson \& Sincock 1992). The receptacle of some Bennettitales is also conical in form and may become filled with sediment (Watson \& Sincock 1992), which is very similar to Zhangwuia. The arrangement of the female units around the receptacle in Zhangwuia appears like that of the seeds and interseminal scales arranged around a receptacle in Bennettitales (e.g., Cycadeoidea, Williamsoniella, Williamsonia, and Buttercarpus (Watson \& Sincock 1992; Rothwell \& Stockey 2002; Stockey \& Rothwell 2003; Crane \& Herendeen 2009; Rothwell et al. 2009)). If this comparison is valid, there seems to be some phylogenetic relationship between Zhangwuia and Bennettitales. The bennettitalean female part would be identical to Zhangwuia if its ovules were completely covered by the adjacent interseminal scales (Fig. 6c, d). Such ovule-enclosure is almost achieved in another fossil taxon, Foxeoidea (Rothwell \& Stockey 2010). The Middle Jurassic age and the morphology of Zhangwuia favour placing Zhangwuia in the Bennettitales. 




(a)


(c)

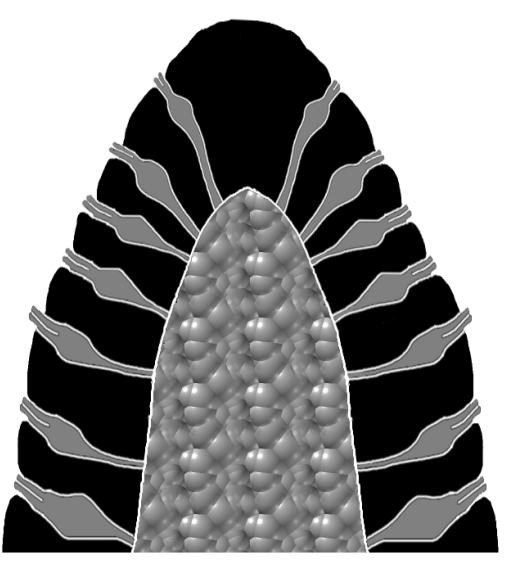

(d)

Figure 6 Diagrams showing the structure of Zhangwuia mira gen. et sp. nov. and its comparison with Bennettitales. (a) Vertical profile of the fossil organ, showing outer foliar parts (of), inner foliar parts (if), female units (fu) with internal space, and the receptacle. Note that the female units are missing in the distal portion. (b) Top view of the reconstructed organ, showing outer foliar parts (of), inner foliar parts (if) in three cycles, and female units around the receptacle. Note the presences of midribs and bent tips in some inner foliar parts. (c) Idealised longitudinal section of the female part in Bennettitales. The ovules (grey) have exserted micropylar tubes and are bracketed by interseminal scales (black). Both ovules and interseminal scales are attached to the receptacle. (d) Idealised longitudinal section of the female part in Zhangwuia. The ovules (grey) are separated from the exterior space by the surrounding tissues (black).
It is worth emphasising that Zhangwuia demonstrates certain features unexpected for any Bennettitales; namely, the ovules in all Bennettitales (including the problematic Foxeoidea of Rothwell \& Stockey 2010) are consistently, more or less, exposed to the exterior, while the ovules of Zhangwuia are inside the female units. An angiosperm flower is typically characterised by a perianth around a gynoecium and/or an androecium (Eames 1961). Similar organisation has been seen in both angiosperms and Bennettitales (Martens 1971; Watson \& Sincock 1992; Biswas \& Johri 1997). A female cone in Bennettitales has a heterogeneous surface comprising micropyle apices and polygonal interseminal scale heads (Watson \& Sincock 1992; Crane \& Herendeen 2009; Rothwell et al. 2009), while the surface of the female part of Zhangwuia is homogeneous, smooth, and integral (Figs 2c, 5e, f) with no trace of a micropylar tube. Furthermore, the locule within the female unit and the ovules inside the locule of Zhangwuia (Fig. 5d) are never seen in other Bennettitales (Rothwell et al. 2009; Table 1), in which the ovules have exserted micropyles and are tightly surrounded by the interseminal scales. Therefore, if Zhangwuia were put into Bennettitales, it would appear that at least some Bennettitales have achieved angio-ovuly through the connation of interseminal scales.

It is noteworthy that Zhangwuia bears a resemblance to angiosperm flowers. The arrangement of the female units in
Zhangwuia may be compared to female flowers in the inflorescence of Araceae because they both have female units that are crowded on the surface of an axis (Barabé et al. 2003, 2004). Because of the breakage, the internal details of the female units of Zhangwuia are observable. As seen in Figs 2e, 5a-d, there are several locules exposed on the broken surface in the female part. These locules are isolated from the exterior space by a wall (Fig. 5a-e), suggesting that a female unit of Zhangwuia has a secluded internal space characteristic of angiosperms. The structure inside the female unit appears to be an ovule (Fig. 5d) as its large size is beyond the scope of microspores, implying the occurrence of angio-ovuly in Zhangwuia. Ovules enclosed before pollination are a feature guaranteeing an angiospermous affinity for the plant in question (Tomlinson \& Takaso 2002; Wang 2010). Therefore, Zhangwuia may have a feature that was formerly only restricted to angiosperms.

Such a mosaic combination of characters spanning angiosperms and Bennettitales makes Zhangwuia especially interesting in plant evolution. The enclosure of the ovule as seen in Zhangwuia is not a singular case. For example, Foxeoidea, an unusual element of Bennettitales, has been anatomically documented in the Cretaceous (Rothwell \& Stockey 2010). According to Rothwell \& Stockey (2010), ovules with micropylar tubes in Foxeoidea are almost completely enclosed by the adjacent interseminal scales that are histologically fused to 
Table 1 Comparison among Zhangwuia, some problematic Bennettitales and Gnetales, as well as angiosperms.

\begin{tabular}{lllll}
\hline & Cycadeoidea & Foxeoidea & Pseudoephedra & Zhangwuia \\
\hline Ovule & Exposed & Almost enclosed & Nucellus enclosed & Enclosed \\
Ovule surrounded by & Interseminal scales & 'Interseminal scales' & Integument & 'Interseminal scales' \\
Interseminal scale tip & Peltate & Peltate? & Not applicable & Not applicable \\
Interseminal scales & Isolated & Connate & Not applicable & Not applicable \\
Micropyle & Exserted & Not exserted & Exserted & Not exserted applicable \\
Internal space & None & None? & ? & Ovarian locule? \\
Peripheral foliar parts & Not differentiated & None & Not differentiated & Differentiated \\
Female part position & Central & $?$ & Central & Central
\end{tabular}

each other and form a continuous layer around the ovules. The ovule-enclosing in Foxeoidea is quite different from the imagined longitudinal folding of a 'megasporophyll' bearing ovules along its margins, as suggested by Arber \& Parkin (1907) and their proponents (Crane 1985; Dilcher 2010). It should be noted that 1) the ovules in Foxeoidea are not completely enclosed, so Foxeoidea falls well within the scope of Bennettitales; and 2) it is still unclear which parts enclose the ovules in Foxeoidea. According to Rothwell \& Stockey (2010), the ovules with micropylar tubes in Foxeoidea are surrounded by the adjacent interseminal scales. However, as the researchers admitted, histologically the 'micropylar tube' is indistinguishable from those of the adjacent interseminal scales because the outer surface of the 'micropylar tube' is never seen, despite its good anatomical preservation (Rothwell \& Stockey 2010, fig. 4.3b, c). This observation makes an alternative interpretation more likely; namely, that their 'micropylar tube' is non-existent, and that the ovule-enclosure is completed by the adjacent interseminal scales. If this is the case, then the ovule-enclosing parts of Foxeoidea will be very similar to Zhangwuia in nature. The near-complete enclosure in Foxeoidea can be taken as a precursor to the complete ovule-enclosure of Zhangwuia. In both cases, the ovule-enclosure is completed by the same structure - the former interseminal scales. The anachronism created by Jurassic Zhangwuia and Cretaceous Foxeoidea does not constitute a serious problem for this interpretation, as Zhangwuia and Foxeoidea may belong to two different parallel lineages.

Parallel to Zhangwuia and Foxeoidea, a possible Gnetalesrelated taxon with typical ephedroid morphology, Pseudoephedra (Liu \& Wang 2016a), bears a solid style (a feature of angiosperms) instead of a micropylar tube as expected in Ephedra. According to molecular studies (Skinner et al. 2004), the placenta and ovarian wall correspond to an axillary branch and a leaf in gymnosperms, respectively. Foxeoidea, Zhangwuia, and Pseudoephedra seem to suggest that there may be a novel evolutionary path for angio-ovuly (Wang et al. 2015): angio-ovuly may be reached by different plant groups in their own ways independently, as suggested by others previously (Krassilov 1977; Wu et al. 2002). The possibility of deriving conduplicate carpels from the assumed 'megasporophylls' which bear ovules along their margins, as assumed by Arber \& Parkin (1907) and their proponents, is reduced to nil since the superficially leaf-like morphology of megasporophyll in Cycas has been experimentally proven to be an artefact due to mechanical pressure (Wang \& Luo 2013). Given all the evidence, angio-ovuly seems to have been reached independently.

\section{Conclusion}

Zhangwuia is a reproductive organ showing a mosaic combination of bennettitalean and angiospermous features. While its lack of exserted micropylar tube makes it atypical in Bennettitales, its ovule enclosed inside the female unit makes Zhangwuia closer to angiosperms. Despite its enigmatic phylogenetic position, Zhangwuia appears to narrow the gap between Bennettitales and angiosperms in an unexpected way.

\section{Acknowledgements}

We thank Ms Chunzhao Wang for her help with SEM observation. This research is supported by the National Natural Science Foundation of China (41688103, 91514302, 91114201, 41572046), the Strategic Priority Research Program (B) of the Chinese Academy of Sciences (grant no XDB26000000) awarded to X. W.; and State Forestry Administration of China (no. 2005-122), the Science and Technology Project of Guangdong (no. 2011B060400011), and the Special Funds for Environmental Projects of Shenzhen (no. 2013-02) awarded to Z. J. L. This is a contribution to UNESCO IGCP632.

\section{Supplementary material}

Supplementary material is available online at https://doi.org/ $10.1017 / \mathrm{S} 1755691018000257$

\section{References}

Arber, E. A. N. \& Parkin, J. 1907. On the origin of angiosperms. Journal of the Linnean Society of London, Botany 38, 29-80.

Barabé, D., Lacroix, C. \& Gibernau, M. 2003. Development of the flower and inflorescence of Arum italicum (Araceae). Canadian Journal of Botany 81, 622-32.

Barabé, D., Lacroix, C., Bruneau, A., Archambault, A. \& Gibernau, M. 2004. Floral development and phylogenetic position of Schismatoglottis (Araceae). International Journal of Plant Sciences $\mathbf{1 6 5}$, 173-89.

Biswas, C. \& Johri, B. M. 1997. The Gymnosperms, 494. Berlin: Springer-Verlag.

Chang, S.-C., Zhang, H., Renne, P. R. \& Fang, Y. 2009. High-precision ${ }^{40} \mathrm{Ar} /{ }^{39} \mathrm{Ar}$ age constraints on the basal Lanqi formation and its implications for the origin of angiosperm plants. Earth and Planetary Science Letters 279, 212-21.

Chang, S.-C., Zhang, H., Hemming, S. R., Mesko, G. T. \& Fang, Y. 2014. ${ }^{40} \mathrm{Ar} /{ }^{39} \mathrm{Ar}$ age constraints on the Haifanggou and Lanqi formations: when did the first flowers bloom? Geological Society, London, Special Publications 378, 277-84.

Chen, W., Ji, Q., Liu, D. Y., Zhang, Y., Song, B. \& Liu, X. Y. 2004. Isotope geochronology of the fossil-bearing beds in the Daohugou area, Ningcheng, Inner Mongolia. Geological Bulletin of China 23, 1165-69.

Crane, P. R. 1985. Phylogenetic analysis of seed plants and the origin of angiosperms. Annals Missouri Botanical Garden 72, 716-93.

Crane, P. R. \& Herendeen, P. S. 2009. Bennettitales from the Grisethrope Bed (Middle Jurassic) at Cayton Bay, Yorkshire, UK. American Journal of Botany 96, 284-95.

Cronquist, A. 1988. The evolution and classification of flowering plants, 555. Bronx: New York Botanical Garden. 
Dilcher, D. L. 2010. Major innovations in angiosperm evolution In Gee, C. T. (ed.). Plants in the Mesozoic time: innovations, phylogeny, ecosystems, 97-116. Bloomington and Indianapolis: Indiana University Press.

Dong, C., Yang, X. \& Zhou, Z. 2016. Fossil plants. In Huang, D. (ed.). Daohugou biota, 252-302. Shanghai: Shanghai Science and Technology.

Eames, A. J. 1961. Morphology of the angiosperms, 518. New York: McGraw-Hill Book Company, Inc.

Han, G., Liu, Z.-J., Liu, X., Mao, L., Jacques, F. M. B. \& Wang, X. 2016. A whole plant herbaceous angiosperm from the Middle Jurassic of China. Acta Geologica Sinica 90, 19-29.

Heinrichs, J., Wang, X., Ignatov, M. S. \& Krings, M. 2014. A Jurassic moss from Northeast China with preserved sporophytes. Review of Palaeobotany and Palynology 204, 50-55.

Herr, J. M. J. 1995. The origin of the ovule. American Journal of Botany 82, 547-64.

Huang, D., Selden, P. S. \& Dunlop, J. A. 2009. Harvestmen (Arachnida: Opiliones) from the Middle Jurassic of China. Naturwissenschaften 96, 955-62.

Huang, D.-Y, Nel, A., Shen, Y., Selden, P. A. \& Lin, Q. 2006. Discussions on the age of the Daohugou fauna - evidence from invertebrates. Progress in Natural Science 16, 308-12.

Huang, D.-Y., Zompro, O. \& Waller, A. 2008a. Mantophasmatodea now in the Jurassic. Naturwissenschaften 95, 947-52.

Huang, D.-Y. \& Nel, A. 2007. A new Middle Jurassic "grylloblattodean" family from China (Insecta: Juraperlidae fam. n.). European Journal of Entomology 104, 837-40.

Huang, D.-Y. \& Nel, A. 2008. New 'Grylloblattida' related to the genus Prosepididontus Handlirsch, 1920 in the Middle Jurassic of China (Insecta: Geinitziidae). Alcheringa 32, 395-403.

Huang, J., Ren, D., Sinitshenkova, N. D. \& Shih, C. 2008b. New fossil mayflies (Insecta: Ephemeroptera) from the Middle Jurassic of Daohugou, Inner Mongolia, China. Insect Science 15, 193-98.

Ji, Q., Chen, W., Wang, W., Jin, X., Zhang, J. P., Liu, Y. Q., Zhang, H., Yao, P. Y., Ji, S. A., Yuan, C. X., Zhang, Y. \& You, H. 2004 Mesozoic Jehol Biota of western Liaoning, China, 375. Beijing: Geological Publishing House.

Ji, Q., Liu, Y., Chen, W., Ji, S. A., Lu, J., You, H. \& Yuan, C. 2005 On the geological age of Daohugou biota. Geological Review 51, $609-12$.

Krassilov, V. A. 1977. The origin of angiosperms. Botanical Review 43, $143-76$

Li, N., Li, Y., Wang, L.-X., Zheng, S.-L. \& Zhang, W. 2004. A new Weltrichia braun in north China with a special bennettitalean male reproductive organ. Acta Botanica Sinica 46, 1269-75.

Liang, J.-H., Vrsansky, P., Ren, D. \& Shih, C. 2009. A new Jurassic carnivorous cockroach (Insecta, Blattaria, Raphidiomimidae) from the Inner Mongolia in China. Zootaxa 1974, 17-30.

Lin, Q.-B., Huang, D.-Y. \& Nel, A. 2008. A new genus of Chifengiinae (Orthoptera: Ensifera: Prophalangopsidae) from the Middle Jurassic (Jiulongshan Formation) of Inner Mongolia, China. Comptes Rendus Palevol 7, 205-09.

Liu, W.-Z., Hilu, K. \& Wang, Y.-L. 2014. From leaf and branch into a flower: Magnolia tells the story. Botanical Studies 55, 28.

Liu, Y., Liu, Y., Li, P., Zhang, H., Zhang, L., Li, Y. \& Xia, H. 2004. Daohugou biota-bearing lithostratigraphic succession on the southeastern margin of the Ningcheng basin, Inner Mongolia, and its geochronology. Regional Geology of China 23, 1180-87.

Liu, Y. \& Ren, D. 2008. Two new Jurassic stoneflies (Insecta: Plecoptera) from Daohugou, Inner Mongolia,China. Progress in Natural Science 18, 1039-42.

Liu, Z.-J. \& Wang, X. 2016a. An enigmatic Ephedra-like fossil lacking micropylar tube from the Lower Cretaceous Yixian formation of Liaoning, China. Palaeoworld 25, 67-75.

Liu, Z.-J. \& Wang, X. 2016b. Yuhania: a unique angiosperm from the Middle Jurassic of Inner Mongolia, China. Historical Biology 29, 431-41.

Martens, P. 1971. Les Gnetophytes. Berlin: Gebrueder Borntraeger.

Melville, R. 1963. A new theory of the angiosperm flower: II. The androecium. Kew Bulletin 17, 1-63.

Miao, Y., Liu, Z.-J., Wang, M. \& Wang, X. 2017. Fossil and living cycads say "No more megasporophylls". Journal of Morphology and Anatomy 1, 107.

Peng, N., Liu, Y., Kuang, H., Jiang, X. \& Xu, H. 2012. Stratigraphy and geochronology of vertebrate fossil-bearing Jurassic strata from Linglongta, Jianchang County, Western Liaoning, Northeastern China. Acta Geologica Sinica 86, 1326-39.

Petrulevicius, J., Huang, D.-Y. \& Ren, D. 2007. A new hangingfly (Insecta: Mecoptera: Bittacidae) from the Middle Jurassic of Inner Mongolia, China. African Invertebrates 48, 145-52.

Pott, C., McLoughlin, S., Wu, S. \& Friis, E. M. 2012. Trichomes on the leaves of Anomozamites villosus sp. nov. (Bennettitales) from the Daohugou beds (Middle Jurassic), Inner Mongolia, China: mechanical defence against herbivorous arthropods. Review of Paleobotany and Palynology 169, 48-60.

Ren, D., Gao, K., Guo, Z., Ji, S., Tan, J. \& Song, Z. 2002. Stratigraphic division of the Jurassic in the Daohugou area, Ningcheng, Inner Mongolia. Geological Bulletin of China 21, 584-91.

Ren, D., Labandeira, C. C., Santiago-Blay, J. A., Rasnitsyn, A., Shih, C., Bashkuev, A., Logan, M. A. V., Hotton, C. L. \& Dilcher, D. 2009. A probable pollination mode before angiosperms: Eurasian, long-proboscid scorpionflies. Science 326, 840-47.

Ren, D., Shih, C., Gao, T., Yao, Y. \& Zhao, Y. 2010. Silent stories, insect fossil treasures from dinosaur era of the Northeastern China, 322. Beijing: Science Press

Rothwell, G. W., Crepet, W. L. \& Stockey, R. A. 2009. Is the anthophyte hypothesis alive and well? New evidence from the reproductive structures of Bennettitales. American Journal of Botany 96, 296-322.

Rothwell, G. W. \& Stockey, R. A. 2002. Anatomically preserved Cycadeoidea (cycadeoidaceae), with a reevaluation of systematic characters for the seed cones of Bennettitales. American Journal of Botany 89, 1447-58.

Rothwell, G. W. \& Stockey, R. A. 2010. Independent evolution of seed enclosure in the Bennettitales: evidence from the anatomically preserved cone Foxeoidea connatum gen. et sp. nov. In Gee, C. T. (ed.). Plants in the Mesozoic time: innovations, phylogeny, ecosystems, 51-64. Bloomington and Indianapolis: Indiana University Press

Selden, P. A., Huang, D.-Y. \& Ren, D. 2008. Palpimanoid spiders from the Jurassic of China. The Journal of Arachnology 36, 30621.

Seward, A. C. 1919. Fossil plants, a text-book for students of botany and geology, 4, 543. Cambridge: The Cambridge University Press.

Sha, J. 2007. Current research on Cretaceous lake systems in northeast China. Cretaceous Research 28, 143-45.

Shen, Y.-B., Chen, P.-J. \& Huang, D.-Y. 2003. Age of the fossil conchostracans from Daohugou of Ningcheng, Inner Mongolia. Journal of Stratigraphy 27, 311-13.

Shih, C., Liu, C. \& Ren, D. 2009. The earliest fossil record of pelecinid wasps (Inseta: Hymenoptera: Proctotrupoidea: Pelecinidae) from Inner Mongolia, China. Annals of the Entomological Society of America 102, 20-38.

Skinner, D. J., Hill, T. A. \& Gasser, C. S. 2004. Regulation of ovule development. Plant Cell 16, S32-45.

Stockey, R. A. \& Rothwell, G. W. 2003. Anatomically preserved Williamsonia (williamsoniaceae): evidence for Bennettitalean reproduction in the Late Cretaceous of western North America. International Journal of Plant Sciences 164, 251-62.

Tan, J. \& Ren, D. 2009. Mesozoic archostematan fauna from China. Beijing: Science Press.

Tomlinson, P. B. \& Takaso, T. 2002. Seed cone structure in conifers in relation to development and pollination: a biological approach. Canadian Journal of Botany 80, 1250-73.

Wang, B., Li, J., Fang, Y. \& Zhang, H. 2009a. Preliminary elemental analysis of fossil insects from the Middle Jurassic of Daohugou, Inner Mongolia and its taphonomic implications. Chinese Science Bulletin 54, 783-87.

Wang, B., Ponomarenko, A. G. \& Zhang, H. 2009b. A new coptoclavid larva (Coleoptera: Adephaga: Dytiscoidea) from the Middle Jurassic of China, and its phylogenetic implication. Paleontological Journal 43, 652-59.

Wang, B., Zhang, H. \& Szwedo, J. 2009c. Jurassic Palaeontinidae from China and the higher systematics of Palaeontinoidea (Insecta: Hemiptera: Cicadomorpha). Palaeontology 52, 53-64.

Wang, B. \& Zhang, H. 2009a. A remarkable new genus of Procercopidae (Hemiptera: Cercopoidea) from the Middle Jurassic of China. Comptes Rendus Palevol 8, 389-94.

Wang, B. \& Zhang, H. 2009b. Tettigarctidae (Insecta: Hemiptera: Cicadoidea) from the Middle Jurassic of Inner Mongolia, China. Geobios 42, 243-53.

Wang, B. \& Zhang, H. 2011. The oldest Tenebrionoidea (Coleoptera) from the Middle Jurassic of China. Journal of Paleontology 85, 266-70.

Wang, X. 2010. The dawn angiosperms. Heidelberg: Springer.

Wang, X., Krings, M. \& Taylor, T. N. 2010a. A thalloid organism with possible lichen affinity from the Jurassic of northeastern China. Review of Palaeobotany and Palynology 162, 567-74.

Wang, X., Zheng, S. L. \& Jin, J. H. 2010b. Structure and relationships of Problematospermum, an enigmatic seed from the Jurassic of China. International Journal of Plant Sciences 171, 447-56.

Wang, X., Liu, Z.-J., Liu, W., Zhang, X., Guo, X., Hu, G., Zhang, S., Wang, Y. \& Liao, W. 2015. Breaking the stasis of current plant systematics. Science \& Technology Review 33, 97-105. 
Wang, X. \& Luo, B. 2013. Mechanical pressure, not genes, makes ovulate parts leaf-like in Cycas. American Journal of Plant Sciences 4, 53-57.

Wang, Y. \& Ren, D. 2009. New fossil palaeontinids from the middle Jurassic of Daohugou, Inner Mongolia, China (Insecta, Hemiptera). Acta Geologica Sinica 83, 33-38.

Watson, J. \& Sincock, C. A. 1992. Bennettitales of the English Wealden. Monograph of Palaeontographical Society 145, 1-228.

Wieland, G. R. 1906. American fossil cycads, 34, 295. Washington, DC: The Wilkens Sheiry Printing Co.

Wilson, C. L. 1937. The phylogeny of the stamen. American Journal of Botany 24, 686-99.

Wu, Z.-Y., Lu, A.-M., Tang, Y.-C., Chen, Z.-D. \& Li, D.-Z. 2002. Synopsis of a new "polyphyletic-polychronic-polytopic" system of the angiosperms. Acta Phytotaxonomica Sinica 40, 289-322.

Zhang, J. 2006. New winter crane flies (Insecta: Diptera: Trichoceridae) from the Jurassic Daohugou formation (Inner Mongolia, China) and their associated biota. Canadian Journal of Earth Science 43, 9-22.

Zhang, J., D'Rozario, A., Yao, J., Wu, Z. \& Wang, L. 2011. A new species of the extinct genus Schizolepis from the Jurassic Daohugou Flora, Inner Mongolia, China with special reference to the fossil diversity and evolutionary implications. Acta Geologica Sinica 85, 471-81.

Zhang, J. F. 2002. Discovery of Daohugou Biota (pre-Jehol Biota) with a discussion on its geological age. Journal of Stratigraphy 26, 173-77.

Zhang, K., Li, J., Yang, D. \& Ren, D. 2009. A new species of Archirhagio Rohdendorf, 1938 from the Middle Jurassic of Inner Mongolia of China (Diptera: Archisargidae). Zootaxa 1984, 6165.

Zhang, X., Liu, W. \& Wang, X. 2017. How the ovules get enclosed in magnoliaceous carpels. PLOS One 12, e0174955.

Zhang, X.-W., Ren, D., Pang, H. \& Shih, C.-K. 2008. A water-skiing chresmodid from the Middle Jurassic in Daohugou, Inner Mongolia, China (Polyneoptera: Orthopterida). Zootaxa 1762, $53-62$.

Zheng, S. \& Wang, X. 2010. An undercover angiosperm from the Jurassic in China. Acta Geologica Sinica 84, 895-902.

Zheng, S.-L., Zhang, L.-J. \& Gong, E.-P. 2003. A discovery of Anomozamites with reproductive organs. Acta Botanica Sinica 45, 66772.

Zhou, Z., Zheng, S. \& Zhang, L. 2007. Morphology and age of Yimaia (ginkgoales) from Daohugou Village, Ningcheng, Inner Mongolia, China. Cretaceous Research 28, 348-62. 